$\xi=-1$

\title{
Conceptualizing the impact of perceived organizational support and psychological contract fulfillment of employees paradoxical intentions of stay and leave
}

\author{
Muhammad Saood Akhtar, Lailawati Mohd Salleh, Nor Hisham Ghafar, \\ MansoorAhmed Khurro, Sultan Adal Mehmood
}

Putra Business School, Universiti Putra Malaysia, Malaysia

*Corresponding authorE-mail: saoodakhtar@hotmail.com

\begin{abstract}
The article presents a comprehensive and detailed conceptual framework on the effects of employees' perceived organizational support on their paradoxical intentions of leaving to and staying with the organization in Psychological Contract Perspective. This study anticipates proposing an applicable technique to examine empirically the interrelationships of employees' perceived organizational support, psychological contract fulfillment, intention to stay and intention to leave. This paper proposes theory-based path model, and possible interrelationships of related constructs such that the future analysis would be based on related statistical methods may include structural equation modeling approach. Although numerous researchers have studied the broad topics of perceived organizational support and employees' turnover intentions, none of those studies has explored the paradoxical and differential impact of perceived organizational support on the intentions of staying and leaving. The innovative propositions using psychological contract fulfillment lenses in the relationship of perceived organizational support with the intention to stay and intention to leave, as explained by psychological contract perspective of social exchange theory would be the originality of this paper and possible contribution to the body of knowledge.
\end{abstract}

Keywords: Perceived organizational support, psychological contract fulfillment, intention to stay, intention to leave, employees' paradoxical intentions

\section{Introduction}

Voluntary turnover and employee retention is extensively studied over the past few decades and yet continue to hold widespread and now global attention in the 21st century [1]. The negative relationship of turnover with firm's financial performance [2][3] has made this area more significant for academicians and practitioners. Empirical evidence suggests that a high rate of voluntary turnover, especially that of skilled and professional employees, is costly for organizations because it affects organizational effectiveness and success [4][5][6][7]. The act of professionals and skilled employees leaving organizations in search of greener pastures, would leave a negative impact particularly on the organization's competitive advantage, morale of other staff, knowledge loss, decreased productivity and work quality, increased recruiting expenses and training costs. [9-12]. A Recent study through a meta-analysis [13] discloses that the overall correlation between voluntary turnover rates and organizational performance is negative. Despite these unfavorable consequences, the voluntary turnover rate across the globe remains relatively high. U.S. Bureau of Labor Statistics (2016),[14] reported that 2.8 million quits (i.e. voluntary turnover) were documented in the month of November 2015 [15]. A more recent study on the US-based marketi shows that the sixty percent of the today's workforce leave their company within three years. Eighty-seven percent of companies reported that the cost to replace each millennial employee they lose was between $\$ 15-25,000$. Fifty-six percent say it takes them from three to seven weeks to arrange a fully productive replacement. An international survey of 2,500 business leaders by Deloitte (2014) revealed that employee retention was one of the top challenges facing businesses and HR managers today. Despite the volumes of research literature already on the subject, voluntary turnover is still a global phenomenon and retaining good employees is still becoming a significant challenge for organizations in achieving their strategic objectives. The phenomena that turnover is still an appealing issue that warrants for more research to be done to understand the causes of voluntary turnover.

Intention to leave (ITL) remained the focus of investigation being the single most influential predictor of actual leaving [16-18]. Traditionally intention to leave (ITL) is used interchangeably with a positive construct of intention to stay (ITS). The emerging concept which explains that high turnover can co-exist with high retention. Howe et al. 2012 [19] argues that intention to leave and intention to stay are different constructs which explain turnover differently. This conceptual study is in line with many research studies[20-22]. This conceptual paper aims to conceptualize the motivators of both intention to stay (ITS) and intention to leave (ITL) to describe the leaving as well as staying behavior of employees.

\section{Theoretical foundation}

Conway \& Briner, (2002) [23] stated that the psychological contract shares some features including the reciprocity norm with other approaches like a social exchange and organizational support According to Blau (1964), "social exchanges are "voluntary actions' which may be initiated by an organization's treatment of its employees, with the expectation that such treatment will eventually be reciprocated in kind." Social Exchange Theory (SET) was originally introduced to examine the interpersonal relationships. However, it has been applied mostly to explain the nature of the relationship between employee and the employer [24]. Social 
exchange relationships develop when an organization or organization's agent shows concern for its employees, it usually results in favorable consequences for the organization [25]. Consequently, active employee attitudes and behaviors are the results of positive social exchange relationships.

Social exchange theory and psychological contract theory share the features of reciprocity and exchange relationship. The norm of reciprocity [26] mainly explain the phenomenon of the psychological contract and also supports its conception as an exchange construct [27]. Previous research studies suggest that the level of reciprocity depends upon the value of the exchange as perceived by employees [28][29]. The organizational support theory postulates that organization values employee's contributions and cares about their well-being and employees have global beliefs regarding this extent. These beliefs are found in the perceptions of the organization's readiness to reward increased work effort and satisfy socioemotional needs [30]. Usually, studies use the global measure of organizational support which adopts the traditional conceptualization of the organization as a "monolithic, undifferentiated identity"[31]. This is also consistent with Levinson's [32] view that employees embody the organization, observing it as having dispositional features including benevolent or malevolent intentions toward them. Employees could consider high-performance human resource practices as a form of investment by the organization [33] The dominant theoretical perspectives in the psychological contract research appear to have much in common with each other, yet they have mostly evolved independently of one another. Conway \& Briner,[34] asserted that while the psychological contract draws upon the theories of social exchange and organizational support, it also contributes uniquely to the understanding of the exchange literature. Social exchange theory provided a theoretical foundation for psychological contract and perceived organizational support. Thus, the two approaches share two key features: the presence of an exchange relationship and reciprocity. Eisenberger [35] conceptually integrated psychological contract and perceived organizational support. Employees used both psychological contracts and perceived organizational support to evaluate their employment relationship. The first key difference is owing to the interpretation of perceptions and beliefs in the evaluation of psychological contract and perception of organizational support. By definition, perceived organizational support captures employees' expectations regarding the level of the organization's commitment to them, while psychological contract encapsulates perceived mutual obligations and the extent of fulfilment of these obligations in the exchange relationship between worker and the organization. Secondly, perceived organizational support focuses on the employer's side of the exchange as it is perceived by the individual employees. Whereas the psychological contract includes a perspective owned by employee and employer, thus, at the very least, it involves two or more parties. Thirdly, perceived organizational support captures an individual's perception of organizational treatment regardless of the explicit or implicit promises made by the organization. In contrast, psychological contract focuses on the discrepancy of what is fulfilled rather than the actual treatment alone.

The argument for the linkages between organizational support, psychological contract and employee outcomes presented in this study hinges on the notions of social exchange theory: reciprocity and exchange relationship. Following this argument, this paper conceptualizes the integration of these theories to share a common interest in examining the impact of employee perception about support from the Organizational Support (POS) and fulfilment of their psychological contract (PCF) on stay and leave intentions. Psychological contract theory is the most cited to explain the phenomenon of talent management in the literature [36] These arguments are developed and further discussed in the next section, following which the framework of this conceptual study is proposed based on the interaction of social exchange, psychological contract, and organizational support theories.

\subsection{Intention to leave (ITL) and intention to stay (ITS)}

Intention to leave refers to "the subjective estimation of an individual regarding the probability of leaving an organization". It is considered "a conscious and deliberate desire to leave the organization within the near future as last part of a sequence in the withdrawal cognition process"[37]. Intention to Leave (ITL) is known as the single best predictor of actual turnover. Its most influential predictors are job satisfaction and organizational commitment, e.g., a meta-analysis found correlations of these constructs with the intention to leave was -0.22 and -0.27 , respectively. In fact, many studies support that job satisfaction and organizational commitment predict intention to leave and intention to leave predicts actual turnover [38] . In addition few well reported predictors of intention to leave are impact of personality and type of job [39] , organizational justice, perceived career growth[40][41] , job characteristics[42][43], perceived organizational and supervisory support[44], affective and normative commitment and goal clarity[45] , organizational climate, commitment and support[46]. However, this study will focus in detail the prediction of ITL through perceived organizational support and psychological contract fulfilment in the following sections.

Intention to stay refers to "employees' conscious and deliberate willingness to stay with the organization"[47]. The recognition of the concept that high turnover can co-exist with high retention has prompted the idea to look into the intentions of employees why they stay with the organizations instead of only focusing the leaving intentions. Furthermore, in retention- turnover research, "intention to leave" has been termed as replacement of "intention to stay." Intention to stay was significantly related to career development, remuneration, person- organization fit (P-O fit), training, and recognition among Australian employees [48], freedom to employees to do their best, opportunities for employee development, employee loyalty and unique contribution to the organization among Indian T\&D Organization employees[49], transformational leadership among IT personnel[50], perceived job security among service sector employees of Turkey[51], learning and development initiatives among engineers in Malaysia[52] and task shifting policy among Canadian personal support workers[53]. ITS and ITL are associated with similar factors. This is demanding the researchers to examine that what are the similarities and differences between the factors influencing to the stay and leave intentions of employees. However, this study focuses in detail on the prediction of ITS through perceived organizational support and psychological contract fulfilment in the following sections.

\subsection{Psychological contract fulfilment (PCF)}

It refers to "employee perceptions regarding the extent to which the organization has delivered on what was promised [54]. It is the degree to which an employee believes his or her organization has fulfilled the obligations of the employer[55] . Psychological contract fulfilment measures the extent to which one party to the contract (employee) deems the other (employer) has met its obligations. From an employee perspective, it takes two forms: perceived employer fulfilment and perceived employee fulfilment. In the case of perceived employer fulfilment, the employee judges the extent to which the employer fulfils its obligations to them. The second form, perceived employee fulfilment emphasizes the employee perceptions of his or her fulfilment of obligations to the employer. This study focuses on perceived employer fulfilment instead of perceived employee fulfilment, as this has been found to be the most important aspect of the psychological contract on explaining employee outcomes. The psychological contract fulfilment is found positively associated with, OCB, organizational commitment, performance, and job satisfaction[56]. The impact of psychological contract fulfilment on employees' intention to stay and intention to leave is discussed in section 5.3 of this paper. 


\subsection{Perceived organizational Support (POS)}

Perceived Organizational support (POS) refers to "the general perception of employees' regarding the degree to which their employer is concerned about their wellness and values their contributions". This construct draws on Social Exchange Theory, which argues that in return for social rewards, recognition, and material benefits employees are motivated to stay and perform at an organization. Considering the exchange relation between organization and employee, provision of support from one party (either organization or employee) makes other reciprocate, which brings benefits for the other party [57] (Rhoades and Eisenberger, 2002). This is the main reason that reciprocity norm is considered as a vital part of developing further relationship forward. The perceptions of the support from organization generate an obliged responsibility in the employees to return the organization for this valuable consideration. Therefore, this reciprocity norm results towards convincing the employee to stay and do something for the organization with a strong bond of affiliation.

Organizations are investing massive amounts on the provision of support to its employees, but the consequences of such investments are still uncertain. A look at literature shows mixed results, some noticed significant (strong) relation of POS and its outcomes [58] other saw significant but moderate or weak link[59-61] while few noticed insignificant association[62-64]. These conflicting findings demand a further investigation [65], which is one of the prime aims of this research endeavour.

\section{Interconnection of the constructs}

\subsection{Similarities and differences between ITL and ITS}

Traditionally ITS and ITL were used interchangeably on the concept that the two constructs are the two opposite sides of the same coin. High ITS represented low ITL and vice versa. Recent evidence, however, suggests the factors influencing employees' intentions to stay are different from those that affect employees' intentions to leave [66]. A recent study conducted by Nancarrow and colleagues has demonstrated that ITS and ITL represent different constructs and do not measure the one [67]. While there is overlap, they suggested that these constructs should be utilized interchangeably with extreme care, principally when measuring these concepts in at workplaces [68]. Researchers have also investigated in different occupational groups including nurses [69], hospitality industry [70], Indian workers[71] and Australian \& British health care workers[72] that different factors effect to both ITS and ITL. More importantly, Howe et al. [73] found that the antecedents of both constructs are not simply the opposite side of each other and forces which drive these two constructs are not exactly the same. The above discussion leads to propose here as under:

Proposition-5: The magnitude of the negative impact of POS on ITL will be different from the magnitude of the positive impact of POS on ITS.

Proposition-6: The mediation effect of PCF will be different for the negative relationship of POS on ITL and positive relationship of POS on ITS.

\subsection{Mediation effect of psychological contract fulfilment}

The psychological contract is the emerging explanation of employees attitudinal and behavioural outcomes at work. Whereas Psychological Contract Fulfilment (PCF) is used as an independent variable, it also explains the relationship of the organizational inducements and the employee outcome. Collins [74] (2010) found that Psychological Contract Fulfilment (PCF) reduced Intention to Leave. Hamilton \& Treuer, [75] (2012) found that PCF is negatively related with employees' ITL in line with the findings of the previous studies [76]. A recent study on generational preferences also supports the negative relationship of Psychological
Contract Fulfilment (PCF) with Intention to Leave (ITL) across different generations [77] . Furthermore, a longitudinal study conducted on fresh graduate followed by 3 -months, 6-months, and 18months after their entry in organizations also support this negative relationship [78]. Apparently, it seems that researchers have studies the individual impact of PCF on ITL directly and through different mediators (e.g. job satisfaction, organizational commitment, trust) and under the moderation effect of few variables (e.g. transactional contract, relational contract, personality traits) but surprisingly the individual link of PCF is missing with ITS. The literature gives support to say that apart from the direct effect of POS on ITL and ITS, POS impacts PCF and PCF impacts ITL. However, the PCF and ITS relationship is derived from theoretical support, and this proposition is the contribution of this study. The above discussion helps us to state the following propositions:

Proposition-3: The psychological contract fulfilment (PCF) will mediate the negative impact of perceived organizational support (POS) on employees' Intention to Leave (ITL).

Proposition 4: The psychological contract fulfilment (PCF) will mediate the positive impact of perceived organizational support (POS) on employees' intention to stay (ITS).

\subsection{Perceived organizational support and intentions to stay}

Employees do not think to leave the organization if they have a positive perception of the support from it[79]. One of the significant outcomes of POS is ITS as reported by Rhoades and Eisenberger [80] (2002) in their meta- analysis. The factors of employee turnover normally explain the reason why employees are leaving the organization but these factor do not highlight the reasons behind the staying employees [81]. Furthermore, Cho, Johanson, and Guchait found the positive correlation between POS and employees' intention to stay. Further, they revealed that POS, being a positive construct has a double impact on ITS as compared to ITL. POS is also found positively related with ITS in a study on Public Sector Employee of Kelang Valley Malaysia. Because only few research studies could be traced to describe the connection of POS with ITS, therefore, this study intent to propose testing the direct relationship between these variables to explain its nature. By following the argument explaining the impact of POS on ITL, we state the following proposition:

Proposition -2: Employees' Perceived Organisational Support (POS) will impact positively on their Intentions to Stay (ITS) with the Organisations.

\subsection{Perceived organizational support and intentions to leave}

The theoretical support explains that, if employees have an active social exchange or reciprocity, they develop a high level of perceptions about organizational support. This perception makes the employees committed to staying in an organization. Conversely, if employees feel that organizational is not inclined to support them, they become less determined to stay in an organization. Organizational support brings positive changes in employees' behaviours and job attitudes e.g. organizational citizenship behaviour, organizational commitment, job satisfaction, engagement, and intentions to leave [82] [83]. Though all these studies reported the significant relation between POS and employee outcomes, this study will focus on examining the effects of POS on employees ITL and ITS.

The results of a meta-analysis (Riggle et al. 2009) [84] concluded that high perceptions of organizational support is significantly related to lowering the intention to leave the organization. This meta-analysis reports $25 \%$ of the variance that POS accounted for intention to leave. Whereas a recent meta-analysis indicated that POS has a reasonable relationship $(r=-0.453 ; \mathrm{p}<0.001$ Predicting 23 percent) with intention to leave (ITL) [85]. 
Apart from above meta-analysis, few recent studies also found the negative relationship of POS with ITL in different contexts. Research conducted on employees of a food industry firm in the Emilia-Romagna region of Italy showed that the significant relation between perceived organizational support (POS) and turnover intentions (TI) is moderated by organizational identificationii. Further, a study on the hospitality worker of India also shows a negative relationship of POS of ITL through relational and transactional psychological contracts [87] [88]. Tuzun \& Kalemc [89] (2012) discovered that employees having low perceptions support from organization, but high perceptions of supervisory support would also report high levels of intentions to quit as compared to employees perceiving low PSS and weak POS. Moreover, Wickramasinghe \& Wickramasinghe, [90] (2011) found that job involvement partially mediates the relationship between perceived organizational support and turnover intention in Sri Lankan formal lean production system employees. The new extensive body of research tends to agree with the negative relationship of POS with ITLiii,iv therefore we develop the following testable proposition. Proposition-1: Employees' Perceived Organizational Support (POS) is negatively related to their Intentions to Leave (ITL) the Organizations.

\section{Research design}

In regarding design, the research, nature of the research problems as specified in the introduction and aim of this study, which then transformed into the conceptual framework, served the basis to decide the type of the research design which may be applied to this study. The intention of the research is to test the validity of the conceptualized model and explain the endogenous and exogenous variables in a particular context. To clarify the nature of the concept, further investigations may help through substantial literature review and expert opinions. Once the conceptual framework is confirmed with the help of past literature and theoretical support, the propositions may be tested by developing/ adapting or adopting the valid and reliable instruments for conducting the survey. As already discussed, tools from existing theories and literature on each variable is an integral part of the study design. Selecting suitable population and doing field survey to collect the data would be the next step. To examine and measure the variables and their interrelationship this phase may opt for structural equation modeling (SEM) which is one of the suitable techniques to assess the relationships between the constructs and to test the propositions. This method combines the principle of factor analysis and multiple regressions and accordingly addresses the testing of the propositions and the model fit. While explaining the relationships among the model constructs, the theories used in conceptualizing the study may be tested with SEM technique.

\section{Conclusion and implications}

This study aims to present and conceptually examine the differential impact of perceived organizational support and psychological contract fulfillment on intention to stay and intention to leave, termed in this paper as Push \& Pull impact. The theoretical model presented in the study postulates that perceived organizational support and psychological contract fulfillment predict to both employees' intention to stay and intention to leave. Psychological contract fulfillment anticipates playing the role of mediator between the relationship of perceived organizational support, and employees' paradoxical intentions of staying with and leaving to the workplace. Finally, the differential impact of psychological contract fulfillment and perceived organizational support predict on employees' staying and leaving intentions.

The possible findings are anticipated to produce meaningful improvement in managing and understanding the paradoxical nature of intention to stay and intention to leave constructs in practice as well as in theory. The main managerial and administrative implication from this study will be that it will challenge the employees' retention strategies which are only based on the factors predicting employees' intention to leave rather than also taking in consideration to the staying intentions of the employees. By investigating the Push and Pull impact of the organizational inducement, employer, especially the HR managers, can effectively manage the retention and turnover of the employees.

The implications for further research would be to test the model for other organizational inducements such as organizational justice, career growth, supervisory support, etc. and job-related inducements such as job characteristics. Furthermore, by testing the proposed model for individual factors such as demographics, previous experiences, and family to work support, etc. might describe the similarities and the differences between the factors affecting employees'intentions to leave and their intentions to stay in the organization.

\section{References}

[1] Hom, Peter W. 2011. "Organizational Exit.” Pp. 325-75 in APA handbook of industrial and organizational psychology, Vol 2: Selecting and developing members for the organization. Washington: American Psychological Association.

[2] . Allen, David, Phil Bryant, and James M. Vardaman. 2010. "Retaining Talent: Replacing Misconceptions With EvidenceBased Strategies." Academy of Management Executive (March 2016).

[3] . Ton, Zeynep and Robert S. Huckman. 2008. "Managing the Impact of Employee Turnover on Performance: The Role of Process Conformance." Organizational Science 19(1):56-68.

[4] . Han, Su Jin, Mark A. Bonn, and Meehee Cho. 2016. "The Relationship between Customer Incivility, Restaurant Frontline Service Employee Burnout and Turnover Intention." International Journal of Hospitality Management 52:97-106.

[5] . Holtom, Brooks C., Terence R. Mitchell, Thomas W. Lee, and Edward J. Inderrieden. 2005. "Shoks as Causes of Turnover: What They Are and How Organisation Manage Them." Human Resource Management 44(3):337-52

[6] . Rahman, Wali and Zekeriya Nas. 2013. "Employee Development and Turnover Intention: Theory Validation." European Journal of Training \& Development 37(6):564-79.

[7] . Zheng, Connie and David Lamond. 2010. "Organisational Determinants of Employee Turnover for Multinational Companies in Asia." Asia Pacific Journal of Management 27(3):42343.

[8] . Allen, David, Phil Bryant, and James M. Vardaman. 2010. "Retaining Talent: Replacing Misconceptions With EvidenceBased Strategies." Academy of Management Executive (March 2016)

[9] . Hancock, Julie I., David G. Allen, Frank A. Bosco, Karen R. Mcdaniel, and Charles A. Pierce. 2011. "Meta-Analytic Review of Employee Turnover as a Predictor of Firm Performance." Journal of Management (October 2011).

[10] . Holtom, Brooks C. and Tyler C. Burch. 2016. "A Model of Turnover-Based Disruption in Customer Services." Human Resource Management Review 26(1):25-36.

[11] . Juhdi, Nurita, Fatimah Pa'wan, and Ram Milah Kaur Hansaram. 2013. "HR Practices and Turnover Intention: The Mediating Roles of Organizational Commitment and Organizational Engagement in a Selected Region in Malaysia." The International Journal of Human Resource Management 24(15):300219

[12] . Ton, Zeynep and Robert S. Huckman. 2008. "Managing the Impact of Employee Turnover on Performance: The Role of Process Conformance." Organizational Science 19(1):56-68.

[13] . Park, Tae-Youn and Jason D. Shaw. 2013. "Turnover Rates and Organizational Performance." American Psychological Asssociation 98(2):268-309

[14] . Memon, Mumtaz Ali, Rohani Salleh, and Noor Rosli Baharom Mohamed. 2016. "The Link between Training Satisfaction, Work Engagement and Turnover Intention." European Journal of Training and Development 40(6).

[15] . Grove. 2015. "The Disappearing Act: Why Millennials Leave Companies - and How L\&D Can Entice Them to Stay." Www.grove.com.

[16] . Liu, Shujie and Anthony J. Onwuegbuzie. 2012. "Chinese Teachers ' Work Stress and Their Turnover Intention.” International Journal of Educational Research 53:160-70. 
[17] . Steel, Robert P. and Nestor K. Ovalle. 1984. "A Review and Meta-Analysis of Research on the Relationship Between Behavioral Intentions and Employee Turnover." Journal of Applied Psychology 69(4):673-86.

[18] . Tekleab, Amanuel G., Riki Takeuchi, and M.Susan Taylor 2005. "Extending the Chain of Relationships among Organizational Justice, Social Exchange, and Employee Reactions: The Role of Contract Violations." Academy of Management Journal 48(1):146-57.

[19] . Howe, Anna L., Debra S. King, Julie M. Ellis, Yvonne D. Wells, and Zhang Wei. 2012. "Stabilising the Aged Care Workforce: An Analysis of Worker Retention and Intention." Australian Health Review 36(1):83-91.

[20] . Chan, Ee-Yuee and Paul Morrison. 2000. "Factors Influencing the Retention and Turnover Intentions of Registered Nurses in a Singapore Hospital.” Nursing \& Health Sciences 2(2):11321.

[21] . Mittal, Vikas, Jules Rosen, and Carrie Leana. 2009. "A DualDriver Model of Retention and Turnover in the Direct Care Workforce." Gerontologist 49(5):623-34

[22] . Nancarrow, Susan, Joanne Bradbury, Sabrina Winona Pit, and Steven Ariss. 2014. "Intention to Stay and Intention to Leave: Are They Two Sides of the Same Coin? A Cross- Sectional Structural Equation Modelling Study among Health and Social Care Workers." Journal of Occupational Health 56(4):292-300

[23] . Conway, Neil and Rob B. Briner. 2002. "Full-Time versus Part-Time Employees : Understanding the Links between Work Status , the Psychological Contract , and Attitudes.” Journal of Vocational Behavior 61:279-301.

[24] . Aryee, Samuel, Fred O. Walumbwa, Reuben Mondejar, and Chris W. L. Chu. 2015. "Accounting for the Influence of Overall Justice on Job Performance: Integrating Self-Determination and Social Exchange Theories." Journal of Management Studies 52(2):231-52.

[25] . Cropanzano, Russell and Marie S. Mitchell. 2005. "Social Exchange Theory: An Interdisciplinary Review Social Exchange Theory : An Interdisciplinary Review." Journal of Management 31(December):874-900

[26] . Gouldner, Alvin W. 1960. "The Norm of Reciprocity: A Preliminary Statement.” American Sociological Review 25(2):161.

[27] . Rousseau, Denise M. and Snehal A. Tijoriwala. 1998. "Assessing Psychological Contracts: Issues, Alternatives and Measures." Journal of Organizational Behavior 19(SUPPL.):679-95.

[28] . Bagger, J. and A. Li. 2014. "How Does Supervisory Family Support Influence Employees' Attitudes and Behaviors? A Social Exchange Perspective." Journal of Management 40(4):1123-50.

[29] . Gould-Williams, Julian Seymour. 2007. "HR Practices, Organizational Climate and Employee Outcomes: Evaluating Social Exchange Relationships in Local Government." The International Journal of Human Resource Management 18(9):162747.

[30] . Eisenberger, Robert, Robin Huntington, Steven Hutchison, and Debora Sowa. 1986. "Perceived Organizational Support." Journal of Applied Psychology 71(3):500-507.

[31] . Reichers, Arnon E. 1985. "Reconceptualization and Review Commitment of Organizational." Academy Of Management 10(3):465-76.

[32] . Levinson, Harry. 1965. "Reciprocation: The Relationship Between Man and Organization." Administrative Science Quarterly $9(4): 370$.

[33] . Allen, David, Phil Bryant, and James M. Vardaman. 2010 "Retaining Talent: Replacing Misconceptions With EvidenceBased Strategies." Academy of Management Executive (March 2016)1.

[34] . Conway, Neil and Rob B. Briner. 2009. Fifty Years of Psychological Contract Research: What Do We Know and What Are the Main Challenges?

[35] . Eisenberger, Robert, Florence Stinglhamber, Christian Vandenberghe, Ivan L. Sucharski, and Linda Rhoades. 2002. "Perceived Supervisor Support: Contributions to Perceived Organizational Support and Employee Retention." The Journal of applied psychology 87(3):565-73

[36] . Ghafar, Nor Hisham and Lailawati Mohd Salleh. 2015. "SYSTEMATIC LITERATURE REVIEW: MAPPING THE TOPOLOGY OF A DECADE OF OF THE TALENT MANAGEMENT RESEARCH." South East Asia Journal of Con- temporary Business, Economics and Law, Vol. 6, Issue 2 (Apr.) ISSN 2289-1560 6(2).

[37] . Mobley, William H., Stanley O. Horner, and A. T. Hollingsworth. 1978. "An Evaluation of Precursors of Hospital Employee Turnover." Journal of Applied Psychology 63(4):408-14.

[38] . Marique, Géraldine and Florence Stinglhamber. 2011. "Identification to Proximal Targets and Affective Organizational Commitment : The Mediating Role of Organizational.” Journal of Personnel Psychology (March 2016).

[39] . Senter, Jenell L. and James E. Martin. 2007. "Factors Affecting the Turnover of Different Groups of Part-Time Workers.' Journal of Vocational Behavior 71:45-68

[40] . Chen, Jian-Qiao et al. 2016. "The Role of Career Growth in Chinese New Employees Turnover Process." Journal of Career Development 43(1):11-25.

[41] . Yang, Yang, Yan-Hui Liu, Jing-Ying Liu, and Hong-Fu Zhang. 2015. "The Impact of Work Support and Organizational Career Growth on Nurse Turnover Intention in China." International Journal of Nursing Sciences 2(2):134-39.

[42] . Birtch, Thomas A. et al. 2015. "A Social Exchange Theory Framework for Understanding the Job Characteristics - Job Outcomes Relationship : The Mediating Role of Psychological Contract Fulfillment." The International Journal of Human Resource Management 5192(February 2016).

[43] . Steyn, Renier and Naseema Vawda. 2014. "Job Characteristics: Their Relationship to Job Satisfaction, Stress and Depression." Journal of psychology in Africa (south of the Sahara, the Caribbean, and Afro-Latin America) 24(3):281-84.

[44] . Korsakienè, Renata, Asta Stankevičienè, Agnè Šimelytė, and Milda Talačkienė. 2014. "Factors Driving Turnover and Retention of Information Technology Professionals." Journal of Business Economics and Management 16(1):1-17.

[45] . Ghosh, Piyali, Rachita Satyawadi, Jagdamba Parasad Joshi, and Mohd. Shadman. 2013. "Who Stays with You? Factors Predicting Employees ' Intention to Stay.” International Journal of Organisational Analysis 21(3).

[46] . Filipova, Anna A. 2011. "Relationships Among Ethical Climates, Perceived Organizational Support, and Intent-to-Leave for Licensed Nurses in Skilled Nursing Facilities." Journal of Applied Gerontology.

[47] . Tett, Robert P. and John F. Meyer. 1993. "Job Satisfaction , Organizational Commitment, Turnover Intention, And Turnover: Path Analyses Based On Meta- Analysis Findings." Personnel Psychology 46

[48] . Chew, Janet and Christopher C. a. Chan. 2008. "Human Resource Practices, Organizational Commitment and Intention to Stay," International Journal of Manpower 29(6):503-22.

[49] . Ghosh, Piyali, Rachita Satyawadi, Jagdamba Parasad Joshi, and Mohd. Shadman. 2013. "Who Stays with You? Factors Predicting Employees ' Intention to Stay.” International Journal of Organisational Analysis 21(3).

[50] . Eom, Mike Tae-in. 2015. "How Can Organization Retain IT Personnel? Impact of IT Manager's Leadership on IT Personnel's Intention to Stay." Information Systems Managemen 32(4):316-30.

[51] . Zeytinoglu, Isik U. et al. 2012. "Security in a Sea of Insecurity: Job Security and Intention to Stay among Service Sector Employees in Turkey." The International Journal of Human Resource Management 23(July 2012):2809-23.

[52] . Anvari, Roya, Nur Naha Abu Mansor, Siti Aisyah Panatik Abdul Rahman, Rabeatul Husna Abdull Rahman, and Mas Idayu Saidi Idrus. 2014. "The Impact of Learning and Development Initiatives on the Retention of Engineers in Malaysian Firms." Procedia - Social and Behavioral Sciences 129:172-77.

[53] . Zeytinoglu, Isik U. et al. 2012. "Security in a Sea of Insecurity: Job Security and Intention to Stay among Service Sector Employees in Turkey." The International Journal of Human Resource Management 23(July 2012):2809-23.

[54] . Rousseau, Denise M. and Snehal A. Tijoriwala. 1998. "Assessing Psychological Contracts: Issues, Alternatives and Measures." Journal of Organizational Behavior 19(SUPPL.):679-95.

[55] . Conway, Neil. .. and Rob. Briner. 2005. Understanding Psychological Contracts at Work : A Critical Evaluation of Theory and Research.

[56] . Coyle-Shapiro, Jacqueline A. M. and Neil Conway. 2005. "Exchange Relationships : Examining Psychological Contracts and Perceived Organizational Support." Journal of Applied Psychology 90(4):774-81 
[57] . Rhoades, Linda and Robert Eisenberger. 2002. "Perceived Organizational Support: A Review of the Literature." Journal of Applied Psychology 87(4):698-714.

[58] . Aryee, Samuel, Fred O. Walumbwa, Reuben Mondejar, and Chris W. L. Chu. 2015. "Accounting for the Influence of Overall Justice on Job Performance: Integrating Self-Determination and Social Exchange Theories.” Journal of Management Studies 52(2):231-52.

[59] . Ahmed, Ishfaq, Muhammad Musarrat Nawaz, Ghulam Ali, and Talat Islam. 2012. "Perceived Organizational Support and Its Outcomes A Meta-Analysis of Latest Available Literature." Personnel Review 41(1):627-39.

[60] . Francis, C. a. 2012. "The Mediating Force of 'Face': Supervisor Character and Status Related to Perceived Organizational Support and Work Outcomes." Journal of Leadership \& Organizational Studies 19(1):58-67

[61] . Sulea, C. et al. 2012. "Work Engagement as Mediator between Job Characteristics and Positive and Negative Extra-Role Behaviors." Career Development International 17(2-3):188207

[62] . Cho, Jeewon and Darren C. Treadway. 2011. "Organizational Identification and Perceived Organizational Support as Mediators of the Procedural Justice-citizenship Behaviour Relationship: A Cross-Cultural Constructive Replication.” European Journal of Work and Organizational Psychology 20(5):631-53

[63] . Tüzün, İpek Kalemci, Çetin Fatih, and Basım H.Nejat. 2014. "The Role of Psychological Capital and Supportive Organizational Practices in the Turnover Process." METU Studies in Development 41(June 2016):85-103.

[64] . Wickramasinghe, Vathsala and Shyama Perera. 2012. "Effects of Perceived Organisation Support, Employee Engagement and Organisation Citizenship Behaviour on Quality Performance.” Total Quality Management \& Business Excellence 25(11-12):1280-94.

[65] . Riggle, Robert J., Diane R. Edmondson, and John D. Hansen 2009. "A Meta-Analysis of the Relationship Between Perceived Organizational Support and Job Outcomes : 20 Years of Research.” Journal of Business Research (October).

[66] . Howe, Anna L., Debra S. King, Julie M. Ellis, Yvonne D. Wells, and Zhang Wei. 2012. "Stabilising the Aged Care Workforce: An Analysis of Worker Retention and Intention." Australian Health Review 36(1):83-91.1

[67] 1 Howe, Anna L., Debra S. King, Julie M. Ellis, Yvonne D. Wells, and Zhang Wei. 2012. "Stabilising the Aged Care Workforce: An Analysis of Worker Retention and Intention." Australian Health Review 36(1):83-91.

[68] . Nancarrow, Susan, Joanne Bradbury, Sabrina Winona Pit, and Steven Ariss. 2014. "Intention to Stay and Intention to Leave: Are They Two Sides of the Same Coin? A Cross- Sectional Structural Equation Modelling Study among Health and Social Care Workers." Journal of Occupational Health 56(4):292-300

[69] . Nancarrow, Susan, Joanne Bradbury, Sabrina Winona Pit, and Steven Ariss. 2014. "Intention to Stay and Intention to Leave: Are They Two Sides of the Same Coin? A Cross- Sectional Structural Equation Modelling Study among Health and Social Care Workers." Journal of Occupational Health 56(4):292-300

[70] . McCarthy, Geraldine, Mark P. Tyrrell, and Geraldine Mccarthy. 2007. "Intention to Leave or Stay in Nursing." Journal of nursing management 15:248-55.

[71] . Cho, Seonghee, Misty M. Johanson, and Priyanko Guchait. 2009. "Employees Intent to Leave: A Comparison of Determinants of Intent to Leave versus Intent to Stay." International Journal of Hospitality Management 28(3):374-81

[72] . Ghosh, Piyali, Rachita Satyawadi, Jagdamba Parasad Joshi, and Mohd. Shadman. 2013. "Who Stays with You? Factors Predicting Employees ' Intention to Stay.” International Journal of Organisational Analysis 21(3)

[73] . Howe, Anna L., Debra S. King, Julie M. Ellis, Yvonne D. Wells, and Zhang Wei. 2012. "Stabilising the Aged Care Workforce: An Analysis of Worker Retention and Intention." Australian Health Review 36(1):83-911

[74] 1 Howe, Anna L., Debra S. King, Julie M. Ellis, Yvonne D. Wells, and Zhang Wei. 2012. "Stabilising the Aged Care Workforce: An Analysis of Worker Retention and Intention." Australian Health Review 36(1):83-91.

[75] . Howe, Anna L., Debra S. King, Julie M. Ellis, Yvonne D. Wells, and Zhang Wei. 2012. "Stabilising the Aged Care Work- force: An Analysis of Worker Retention and Intention.” Australian Health Review 36(1):83-911

[76] 1 Howe, Anna L., Debra S. King, Julie M. Ellis, Yvonne D. Wells, and Zhang Wei. 2012. "Stabilising the Aged Care Workforce: An Analysis of Worker Retention and Intention." Australian Health Review 36(1):83-91.

[77] Collins, Michael D. 2010. "International Journal of Hospitality Management The Effect of Psychological Contract Fulfillment on Manager Turnover Intentions and Its Role as a Mediator in a Casual, Limited-Service Restaurant Environment.” International Journal of Hospitality Management 29(4):736-42.

[78] . Hamilton, Sigrid M. and Kathryn Treuer. 2012. "An Examination of Psychological Contracts, Careerism and ITL." Career Development International 17(5):475-94.

[79] . Turnley, William H., Mark C. Bolino, Scott W. Lester, and James M. Bloodgood. 2003. "The Impact of Psychological Contract Fulfillment on the Performance of In-Role and Organizational Citizenship Behaviors.” Journal of Management 29(2):187-206

[80] . Lub, Xander D., P.Matthijs Bal, Robert J. Blomme, and René Schalk. 2015. "One Job, One Deal...or Not: Do Generations Respond Differently to Psychological Contract Fulfillment?" The International Journal of Human Resource Management (April):1-28

[81] . Karagonlar, Gökhan, Robert Eisenberger, and Justin Aselage. 2016. "Reciprocation Wary Employees Discount Psychological Contract Fulfillment." Journal of Organizational Behavior 37:23-40.

[82] . Perryer, Chris, Catherine Jordan, Travaglione Antonio, and Ian Firns. 2010. "Predicting Turnover Intentions: The Interactive Effects of Organizational Commitment and Perceived Organizational Support." Journal of Small Business and Enterprise Development 12(4):564-78.

[83] . Rhoades, Linda and Robert Eisenberger. 2002. "Perceived Organizational Support: A Review of the Literature.” Journal of Applied Psychology 87(4):698-714.1

[84] 1 Rhoades, Linda and Robert Eisenberger. 2002. "Perceived Organizational Support: A Review of the Literature." Journal of Applied Psychology 87(4):698-714.

[85] . Zhang, Yujing and Jiancheng Chen. 2010. "Motivational Mechanism Research of on-the-Job Embeddedness Effects on Intentions to Stay." Pp. 3-6 in International Conference on Management and Service Science, MASS 2010.

[86] . Anvari, Roya, Nur Naha Abu Mansor, Siti Aisyah Panatik Abdul Rahman, Rabeatul Husna Abdull Rahman, and Mas Idayu Saidi Idrus. 2014. "The Impact of Learning and Development Initiatives on the Retention of Engineers in Malaysian Firms." Procedia - Social and Behavioral Sciences 129:172-77.

[87] . Rodrigues, Ricardo, David Guest, Teresa Oliveira, and Kerstin Alfes. 2015. "Who Benefits from Independent Careers? Employees, Organizations, or Both?" Journal of Vocational Behavior 91:23-34.

[88] . Riggle, Robert J., Diane R. Edmondson, and John D. Hansen. 2009. "A Meta-Analysis of the Relationship Between Perceived Organizational Support and Job Outcomes : 20 Years of Research.” Journal of Business Research (October).

[89] . Ahmed, Ishfaq, Muhammad Musarrat Nawaz, Ghulam Ali, and Talat Islam. 2012. "Perceived Organizational Support and Its Outcomes A Meta-Analysis of Latest Available Literature." Personnel Review 41(1):627-39.

[90] . Anvari, Roya, Nur Naha Abu Mansor, Siti Aisyah Panatik Abdul Rahman, Rabeatul Husna Abdull Rahman, and Mas Idayu Saidi Idrus. 2014. "The Impact of Learning and Development Initiatives on the Retention of Engineers in Malaysian Firms." Procedia - Social and Behavioral Sciences 129:172-77 